\title{
Biologically relevant macrocyclic complexes of copper spectral, magnetic, thermal and antibacterial approach
}

\author{
Sulekh Chandra* and Rachna Gupta \\ Department of Chemistry, National Physical Laboratory, University of Delhi, J.L. Nehru Marg, New Delhi 110002 , \\ India
}

Nidhi Gupta and Sukhwant Singh Bawa

Zakir Hussain College, Dr. K.S. Krishnan Marg, New Delhi 110012, India

Received 7 February 2005; accepted 6 July 2005

\begin{abstract}
Copper(II) macrocyclic complexes have been synthesized with five novel ligands: $\mathrm{L}^{1}-1,7,10,16$-tetraaza-2,6,11,15tetraone-4,13-dithiacycloocta-decane, $\quad \mathrm{L}^{2}$-1,7,11,17-tetraaza-2,6,12,16-tetraone-4,14-dithia-cyclocosane, $\mathrm{L}^{3}$-1,7,10, 13,19,22-hexaaza-2,6,14,18-tetraone-4,16-dithiacyclo-tetracosane, L ${ }^{4}-1,7,14,20$,tetraaza-2,6,15,19-tetraone-4,17,dithiatricyclo $\left[22,4, \mathrm{O}^{21,26}, \mathrm{O}^{8,13}\right]$ hexacosa-8,10,12,21,23,25-hexene, $\mathrm{L}^{5}-1,7,13,19,25,26$-hexaaza-2,6,14,18 tetraone4,16 dithia tricyclo $\left[23,3,1, \mathrm{I}^{8,12}\right]$ hexacosa $[8(26), 10,12,20(25), 22,24]$ hexane and characterized by elemental analysis, molar conductance, magnetic susceptibility, i.r, u.v.-vis, EPR spectral studies, thermal studies and electrochemical properties. The molar conductance measurements of the complexes in DMSO correspond to $1: 2$ electrolytes. $g$-Values are calculated for all of the complexes in the polycrystalline form as well as in DMSO solution. On the basis of i.r, electronic and EPR spectral studies a square planar geometry has been assigned to these complexes. Cyclic voltammograms for all the complexes are similar to quasi-reversible redox processes $\mathrm{Cu}^{\mathrm{II}} \mathrm{Cu}^{\mathrm{II}} \leftrightarrows$ $\mathrm{Cu}^{\mathrm{II}} \mathrm{Cu}^{\mathrm{I}} \leftrightarrows \mathrm{Cu}^{\mathrm{I}} \mathrm{Cu}^{\mathrm{I}}$. The complexes were also evaluated against the growth of bacteria (S. fecalis and E.coli) in vitro.
\end{abstract}

\section{Introduction}

Macrocyclic complexes are thermodynamically more stable and more selective metal ion chelates than open chain analogues. So the study of macrocyclic complexes is a growing class of research [1-4]. Transition metal complexes of synthetic marcocyclic ligands are of significance because porphyrins and cobalamines play vital roles in biological systems, such chelating molecules are important since they are capable of furnishing an environment of controlled geometry and ligand field strength. Macrocyclic Schiff base nitrogen donor ligands have received special attention because of their mixed hard-soft donor character and versatile coordination behaviour [5-6]. Azatype ligands appear as very promising to be used as antifertile, antibacterial, antifungal and for other biological properties [7-11]. Transition metal complexes have received much attention as catalyst in oxidation and epoxidation processes $[12,13]$. Macrocyclic complexes containing manganese and copper centre have been prepared to study cyclic voltammetry and biological activity [14, 15].

In order to synthesise the requisite type of superstructured macrocycles, the obvious approach is to first prepare the more basic macrocyclic ligand and then add a suitable metal ion to the ligand. However if the ligand

\footnotetext{
* Author for correspondence: E-mail: root@csnpl.ren.nic.in
}

yield is low, it can be characterized by various studies and then the complexes can be prepared by the template method. As in the present case, we intend to explore the synthesis of new polyaza macrocyclic complexes. Along this route some hexaaza macrocyclic ligands and complexes have been isolated and their spectral, magnetic, electrochemical and biological properties are explored.

\section{Physical measurements}

IR spectra were recorded on a Perkin-Elmer 137 instrument in $\mathrm{KBr}$ pellets. Microanalyses $(\mathrm{C}, \mathrm{H}$ and $\mathrm{N}$ ) of these complexes were carried out on a Carlo-Erba 1106 elemental analyzer. Electronic spectra were recorded in DMSO solution on a Shimadzu UV mini - 1240 spectrophotometer. The molar conductance was measured on an Elico conductivity bridge (type CM82T). Magnetic moment measurements (Gouy balance) were made at room temperature using $\mathrm{CuSO}_{4} \cdot 5 \mathrm{H}_{2} \mathrm{O}$ as calibrant. EPR spectra of the complexes were recorded as polycrystalline samples and in the DMSO solution, at room temperature on an $\mathrm{E}_{4}$-EPR spectrometer using DPPH as the $g$-marker. Electrochemical procedures were carried out on a PAR 173 potentiostat/galvanostat instrument with a PAR 175 model universal programmer coupled to a PAR 179 digital coulometer. The voltammograms and the simultaneous current intensity-time plots for electrolysis were registered in a $\mathrm{X}-\mathrm{Y}$ Houston- 
Ommigraphic 2000 recorder. Cyclic voltammetry and controlled potential electrolysis coulometry at room temperature (r.t.) (approximately $25^{\circ} \mathrm{C}$ ) under either an inert $\left(\mathrm{N}_{2}\right)$ or a saturated $\mathrm{CO}_{2}$ atmosphere were performed in a specially designed air-tight electrochemical cell with a double three-electrode system, to obtain cyclic voltammograms "in situ" for the electrolytically generated products. All electrodes were introduced into the cell body by means of an ST glass joint and caps with Teflon-faced-silicon septa were used for the needles that bubble and exit gases. CV measurements were performed using a reticulated vitreous carbon (ERG) and $\mathrm{GC}$ as working and $\mathrm{Ag} / \mathrm{AgCl}$ reference electrodes, respectively. The last one was supplied by a vycor tip glass end. The platinum spiral wire counter electrode was separated by means of a salting bridge through sinterized glass ends. In vitro antibacterial activities of these complexes were tested using the paper disc diffusion method. The chosen strains were Streptococcus fecalis (Gram positive) and Escherichia coli (Gram negative). The liquid medium containing the bacterial subcultures was autoclaved for $20 \mathrm{~min}$ at $121^{\circ} \mathrm{C}$ and at $15 \mathrm{lb}$ pressure before inoculation. The bacteria were then cultured for $24 \mathrm{~h}$ at $36{ }^{\circ} \mathrm{C}$ in an incubator. Nutrient agar was poured onto a plate and allowed to solidify. The test compounds (DMSO solutions) were added dropwise to a $10 \mathrm{~mm}$ diameter filter paper disc placed at the centre of each agar plate. The plates were then kept at $5{ }^{\circ} \mathrm{C}$ for $1 \mathrm{~h}$, then transferred to an incubator maintained at $36{ }^{\circ} \mathrm{C}$. The width of the growth inhibition zone around the disc was measured after $24 \mathrm{~h}$ incubation. Four replicas were made for each treatment. Thermogravimetric analysis measurements were carried out using a Metter Toledo thermal analysis system. The experiments were done in nitrogen atmosphere using alumina powder as reference material. The weight of sample taken was $8-10 \mathrm{mg}$ and heating rate was $10^{\circ} \mathrm{C} /$ $\min$.

\section{Experimental}

\section{Synthesis of complexes}

To a hot EtOH solution of $\mathrm{L}^{1}$; ethylenediamine $(2 \mathrm{mmol}$; $0.158 \mathrm{gm}), \mathrm{L}^{2} ; 1,3$, diaminopropane $(2 \mathrm{mmol} ; 0.17 \mathrm{gm})$, $\mathrm{L}^{3}$; Diethylenetriamine (2 mmol; $\left.0.18 \mathrm{gm}\right), \mathrm{L}^{4}$; o-phenylenediamine ( $2 \mathrm{mmol} ; 0.21 \mathrm{gm}), \mathrm{L}^{5} ; 2,6$-diaminopyridine
( $2 \mathrm{mmol}$; $0.22 \mathrm{gm}$ ), an EtOH solution $(2 \mathrm{mmol})$ of metal salt were added. The precipitate which formed readily dissolved and then to it an EtOH solution $(2 \mathrm{mmol}$; $0.376 \mathrm{gm}$ ) of thiodiglycolic acid was added. The resulting solution was refluxed for $6-9 \mathrm{~h}$ at $79-80{ }^{\circ} \mathrm{C}$. On cooling, to room temperature a colored complex precipitated. It was filtered, washed with cold EtOH and dried under vacuum over $\mathrm{P}_{4} \mathrm{O}_{10}$.

\section{Results and discussions}

A new series of binuclear $\mathrm{Cu}$ (II) complexes $\left[\mathrm{M}_{2} \mathrm{LX}_{2}\right] \mathrm{X}_{2}$ $\left[\mathrm{M}=\mathrm{Cu}\right.$ and $\left.\mathrm{X}=\mathrm{NO}_{3}\right]$ have been prepared. The complexes were stable in the atmosphere and were polycrystalline. On the basis of elemental analysis data (Table 1) all the complexes have the general composition $\mathrm{Cu}_{2} \mathrm{LX}_{4}$. The molar conductance measurements in DMSO shows that the complexes are 1:2 electrolytes, so the complexes may be formulated as $\left[\mathrm{Cu}_{2} \mathrm{LX}_{2}\right] \mathrm{X}_{2}$ and $\mathrm{X}=\mathrm{NO}_{3}^{-}$. The effective magnetic moments of all complexes at room temperature lie in the range 1.54-1.62 B.M., corresponding to one unpaired electron in a square planar environment [16] (Table 2). The magnetic moment was found to be 1.54-1.62 and $1.25-1.5$ at $300 \mathrm{~K}$ and $77 \mathrm{~K}$; this decrease of magnetic moment with the decrease of temperature indicates some anti-ferromagnetic interaction in these complexes [17]. The i.r spectra of the complexes show four new bands corresponding to amide groups in the regions 1638-1647, 1553-1582, 1380-1385 and 698-779 $\mathrm{cm}^{-1}$ These bands may be assigned to amide $\mathrm{I}[v(\mathrm{C}=\mathrm{O})]$, amide II $[v(\mathrm{C}-\mathrm{N})+\delta(\mathrm{N}-\mathrm{H})]$, amide III $[\delta(\mathrm{N}-\mathrm{H})]$ and amide IV $[\delta(\mathrm{C}=\mathrm{O})]$, respectively, supporting the macrocyclic structure. The complexes exhibits three NO stretching bands at $1430-1435 \mathrm{~cm}^{-1}\left(v_{1}\right), 1374$ $1377 \mathrm{~cm}^{-1}\left(v_{3}\right), 1209-1203 \mathrm{~cm}^{-1}\left(v_{5}\right), 1010-1013 \mathrm{~cm}^{-1}$ $\left(v_{2}\right)$ and $839-835 \mathrm{~cm}^{-1}\left(v_{6}\right)$. The absence of a broad band at $1390 \mathrm{~cm}^{-1}$ and separation between $v_{1}$ and $v_{5}$ of $\sim 125$ indicates the coordination of both nitrate groups as unidentate [18] in these complexes.

Electronic spectra show bands near 15,382-15,780 and $21,752-22,980 \mathrm{~cm}^{-1}$ and charge transfer bands above $30,000 \mathrm{~cm}^{-1}$ (Table 2) which suggests the square planar geometry for the bimetallic complexes. The two bands may be assigned as probable the transitions

Table 1. Molar conductance and elemental analysis data of binuclear $\mathrm{Cu}(\mathrm{II})$ complexes

\begin{tabular}{|c|c|c|c|c|c|c|c|c|c|}
\hline \multirow[t]{2}{*}{ Complexes } & \multirow{2}{*}{$\begin{array}{l}\text { M.W. Calcd. } \\
\text { (Found) }\end{array}$} & \multirow{2}{*}{$\begin{array}{l}\text { Molar cond. } \\
\Omega^{-1} \mathrm{~cm}^{2} \mathrm{~mol}^{-1}\end{array}$} & \multirow{2}{*}{ Colour } & \multirow{2}{*}{$\begin{array}{l}\text { Yield } \\
(\%)\end{array}$} & \multirow{2}{*}{$\begin{array}{l}\text { M.Pt. } \\
\left({ }^{\circ} \mathrm{C}\right)\end{array}$} & \multicolumn{4}{|c|}{ Element analysis (Calcd. Found) } \\
\hline & & & & & & $\mathrm{Cu}$ & $\mathrm{C}$ & $\mathrm{H}$ & $\mathrm{N}$ \\
\hline$\left[\mathrm{Cu}_{2} \mathrm{~L}_{1}\left(\mathrm{NO}_{3}\right)_{2}\right]\left(\mathrm{NO}_{3}\right)_{2} \mathrm{Cu}_{2} \mathrm{C}_{12} \mathrm{H}_{20} \mathrm{~N}_{8} \mathrm{~S}_{2} \mathrm{O}_{16}$ & $724(723.17)$ & 237 & Green & 69 & 175 & $17.95(8.0)$ & $19.9(19.9)$ & $2.8(2.85)$ & 15.5 \\
\hline$\left[\mathrm{Cu}_{2} \mathrm{~L}_{2}\left(\mathrm{NO}_{3}\right)_{2}\right]\left(\mathrm{NO}_{3}\right)_{2} \mathrm{Cu}_{2} \mathrm{C}_{14} \mathrm{H}_{24} \mathrm{~N}_{8} \mathrm{~S}_{2} \mathrm{O}_{16} \mathrm{~N}_{4}$ & $752(751.29)$ & 262 & $\begin{array}{l}\text { Bluish } \\
\text { green }\end{array}$ & 64 & 172 & $17.3(17.3)$ & $22.3(22.4)$ & $3.2(3.2)$ & $7.4(7.5)$ \\
\hline$\left[\mathrm{Cu}_{2} \mathrm{~L}_{3}\left(\mathrm{NO}_{3}\right)_{2}\right]\left(\mathrm{NO}_{3}\right)_{2} \mathrm{Cu}_{2} \mathrm{C}_{16} \mathrm{H}_{30} \mathrm{~N}_{10} \mathrm{~S}_{2} \mathrm{O}_{16}$ & $810(809.47)$ & 233 & Green & 67 & 192 & $16.0(16.1)$ & $23.7(23.8)$ & $3.7(3.8)$ & $17.3(17.3)$ \\
\hline$\left[\mathrm{Cu}_{2} \mathrm{~L}_{4}\left(\mathrm{NO}_{3}\right)_{2}\right]\left(\mathrm{NO}_{3}\right)_{2} \mathrm{Cu}_{2} \mathrm{C}_{20} \mathrm{H}_{20} \mathrm{~N}_{8} \mathrm{~S}_{2} \mathrm{O}_{16}$ & $820(819.89)$ & 217 & Green & 52 & 183 & $15.85(15.9)$ & $29.3(29.3)$ & $2.4(2.5)$ & $13.65(13.7)$ \\
\hline$\left[\mathrm{Cu}_{2} \mathrm{~L}_{5}\left(\mathrm{NO}_{3}\right)_{2}\right]\left(\mathrm{NO}_{3}\right)_{2} \mathrm{Cu}_{2} \mathrm{C}_{18} \mathrm{H}_{18} \mathrm{~N}_{10} \mathrm{~S}_{2} \mathrm{O}_{16}$ & $822(821.29)$ & 232 & $\begin{array}{l}\text { Bluish } \\
\text { green }\end{array}$ & 62 & 175 & $15.8(15.9)$ & $26.3(26.3)$ & $2.2(2.2)$ & $17.0(17.1)$ \\
\hline
\end{tabular}


Table 2. Electronic and ESR spectral bands of binuclear $\mathrm{Cu}(\mathrm{II})$ complexes

\begin{tabular}{|c|c|c|c|c|c|c|c|}
\hline Complexes & Spectral bands $\left(\mathrm{cm}^{-1}\right)$ & $\mu_{\text {eff }}$ (B.M.) & $g_{\|}$ & $\mathrm{g}_{\perp}$ & $g_{\text {iso }}$ & $A_{\text {iso }}$ & $A_{\|}$ \\
\hline$\left[\mathrm{Cu}_{2} \mathrm{~L}_{1}\left(\mathrm{NO}_{3}\right)_{2}\right]\left(\mathrm{NO}_{3}\right)_{2}^{\mathrm{a}}$ & 15382,21752 & 1.57 & 2.17 & 2.062 & 2.085 & - & - \\
\hline$\left[\mathrm{Cu}_{2} \mathrm{~L}_{2}\left(\mathrm{NO}_{3}\right)_{2}\right]\left(\mathrm{NO}_{3}\right)_{2}^{\mathrm{b}}$ & 15501,22269 & 1.54 & 2.20 & 2.061 & 2.114 & 81.6 & 182 \\
\hline$\left[\mathrm{Cu}_{2} \mathrm{~L}_{3}\left(\mathrm{NO}_{3}\right)_{2}\right]\left(\mathrm{NO}_{3}\right)_{2}^{\mathrm{a}}$ & 15780,22742 & 1.60 & 2.18 & 2.027 & 2.091 & - & - \\
\hline$\left[\mathrm{Cu}_{2} \mathrm{~L}_{4}\left(\mathrm{NO}_{3}\right)_{2}\right]\left(\mathrm{NO}_{3}\right)_{2}^{\mathrm{b}}$ & 15479,21777 & 1.60 & 2.24 & 2.060 & 2.117 & 78.7 & 182 \\
\hline$\left[\mathrm{Cu}_{2} \mathrm{~L}_{5}\left(\mathrm{NO}_{3}\right)_{2}\right]\left(\mathrm{NO}_{3}\right)_{2}^{\mathrm{b}}$ & 15672,22980 & 1.57 & 2.27 & 2.064 & - & - & - \\
\hline
\end{tabular}

${ }^{a}$ as polycrystalline sample at room temperature.

$\mathrm{b}_{\text {as Polycrystalline sample at LNT. }}$

$g_{\perp}=\left(3 g_{\text {iso }}-g_{\|}\right) / 2$.

$\mathrm{A}_{\perp}=\left(3 A_{\text {iso }}-A_{\|}\right) / 2$.

${ }^{2} A_{1 g} \leftarrow{ }^{2} B_{1 g}\left(a_{1} g^{2} \cdot b_{1} g^{2} \cdot b_{1} g^{1} \rightarrow a_{1} g^{1} \cdot b_{1} g^{2}\right),{ }^{2} E_{g} \leftarrow$ ${ }^{2} B_{1 g}\left(e g^{4} \cdot a_{1} g^{2} \cdot b_{1} g^{1} \rightarrow e g^{3} \cdot a_{1} g^{2} \cdot b_{1} g^{2}\right)$

The X-band room temperature EPR spectra of polycrystalline samples of the complexes were recorded. The parameters $g$ and $G$ obtained from the spectra are listed in (Table 2). The $g_{\|}, A_{\|}$and $A_{\mathrm{i}}$ values for fourcoordinate copper(II) complexes with different ligands confirms the square planar geometry around the metal ion $[19,20]$. Results of antibacterial screening are as shown in Figure 1.

The thermal stabilities of the complexes were investigated using TGA. The TGA curves were obtained at a heating rate of $10{ }^{\circ} \mathrm{C} / \mathrm{min}$ in $\mathrm{N}_{2}$ atmosphere over the temperature range of $25-650.0^{\circ} \mathrm{C}$ and their decompositions started in this temperature range and were completed at $530.0^{\circ} \mathrm{C}$. No weight loss up to $100{ }^{\circ} \mathrm{C}$ indicates the absence of lattice water molecules in all complexes. The complexes decomposed and procured $2 \mathrm{CuO}$ as a residue in three steps in the temperature ranges $185.0-268.0,265.0-310.0$ and $310.0-530.0^{\circ} \mathrm{C}$. The three stages of the decomposition of the $\mathrm{Cu}(\mathrm{II})$ complexes are irreversible. (Table 3)

The cyclic voltammograms for the copper(II) complexes at negative potential were recorded in the potential range 0 to $-1.5 \mathrm{~V}$; the data are summarised in (Table 4). The cyclic voltammograms were obtained for the complexes $\left[\mathrm{Cu}_{2} \mathrm{~L}^{1}\right]$ and $\left[\mathrm{Cu}_{2} \mathrm{~L}^{5}\right]$ in the cathodic region. All the binuclear $\mathrm{Cu}$ (II) complexes shows two step, one-electron, quasi-reversible reduction waves. Controlled potential electrolysis performed at a potential of $100 \mathrm{mV}$ more negative than the reduction wave indicates the consumption of one electron per molecule for both the first and second reduction wave. Cyclic voltammograms for all the complexes are similar and involve two quasi-reversible redox processes. Even though all the complexes both the metal ions have the same geometry and same environment, two reduction waves are obtained in the cathodic region corresponding to stepwise one-electron reductions through a $\mathrm{Cu}^{\mathrm{I}} \mathrm{Cu}^{\mathrm{II}}$ intermediate to give a binuclear $\mathrm{Cu}^{\mathrm{I}}$ species. In spite of the ligands being symmetrical, their bicopper(II) complexes show two quasi-reversible reduction waves [21]. The two redox processes are represented as follows:

$$
\mathrm{Cu}^{\mathrm{II}} \mathrm{Cu}^{\mathrm{II}} \leftrightarrows \mathrm{Cu}^{\mathrm{II}} \mathrm{Cu} \leftrightarrows \mathrm{Cu}^{\mathrm{I}} \mathrm{Cu}^{\mathrm{I}}
$$

The reason for the observation of two reduction waves may be due to electronic exchange between the metal ions: after the first one-electron reduction some of the electron density is transferred from the reduced metal

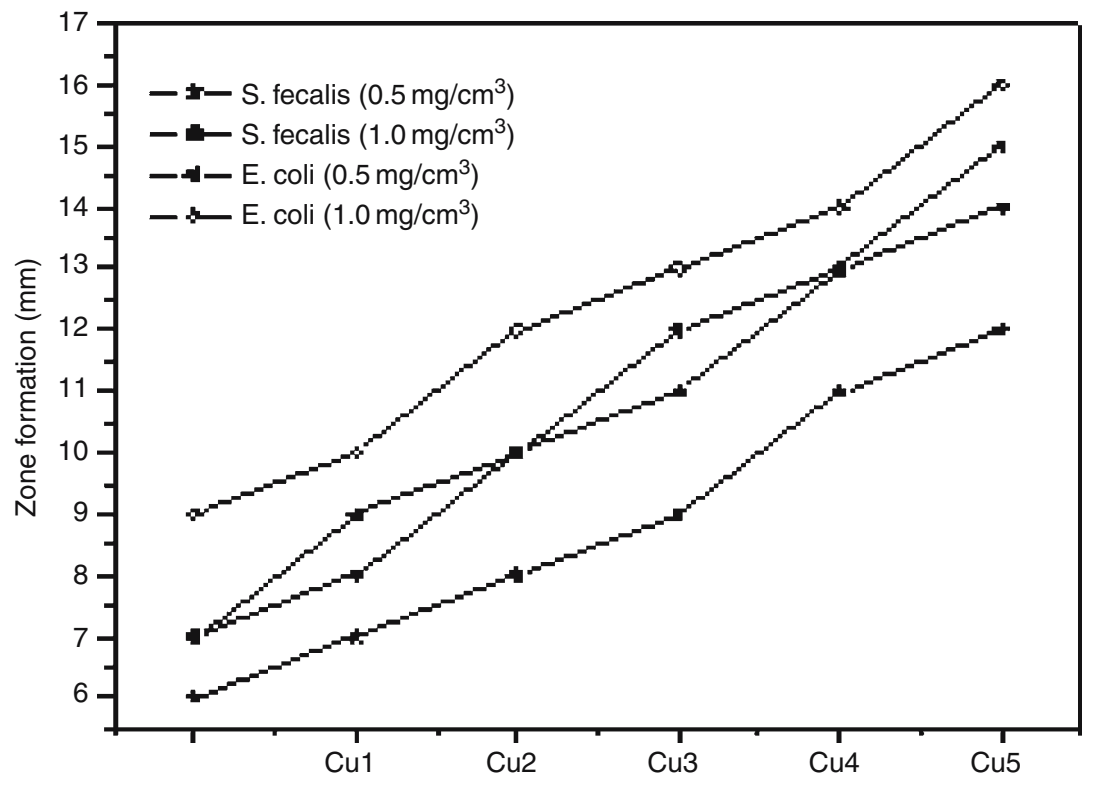

Fig. 1. Antibacterial activity shown by the complexes. 
Table 3. TGA data of the complexes [weight loss \%, found (calculated)]

\begin{tabular}{|c|c|c|c|c|}
\hline Complexes & First step $\left({ }^{\circ} \mathrm{C}\right)$ & Second step $\left({ }^{\circ} \mathrm{C}\right)$ & Third step $\left({ }^{\circ} \mathrm{C}\right)$ & Residue (\%) Found (Calcd.) \\
\hline \multirow{2}{*}[\mathrm{Cu}_{2}\mathrm{L}_{1}(\mathrm{NO}_{3})_{2}]{$\left(\mathrm{NO}_{3}\right)_{2}$} & $185.0-268.0$ & $268.0-305.0$ & $305.0-530.0$ & $22.51(20.97)$ \\
\hline & $33.0(33.15)$ & $14.55(14.86)$ & 29.94(31.02) & $77.64(79.03)^{\mathrm{a}}$ \\
\hline \multirow[t]{2}{*}[\mathrm{Cu}_{2}\mathrm{L}_{2}(\mathrm{NO}_{3})_{2}]{$\left(\mathrm{NO}_{3}\right)_{2}$} & $185.0-267.0$ & $267.0-300.0$ & $300.0-525.0$ & $21.53(20.15)$ \\
\hline & $30.89(31.91)$ & 18.03(18.12) & $29.55(29.82)$ & $78.47(79.85)^{\mathrm{a}}$ \\
\hline \multirow[t]{2}{*}[\mathrm{Cu}_{2}\mathrm{L}_{3}(\mathrm{NO}_{3})_{2}]{$\left(\mathrm{NO}_{3}\right)_{2}$} & $180.0-250.0$ & $250.0-300.0$ & $300.0-528.0$ & $20.30(19.55)$ \\
\hline & $29.50(29.80)$ & $22.88(23.11)$ & $27.32(27.54)$ & $79.70(80.45)^{\mathrm{a}}$ \\
\hline \multirow{2}{*}[\mathrm{Cu}_{2}\mathrm{L}_{4}(\mathrm{NO}_{3})_{2}]{$\left(\mathrm{NO}_{3}\right)_{2}$} & $185.0-255.0$ & $255.0-310.0$ & $310.0-530.0$ & $19.1(19.40)$ \\
\hline & $29.50(29.14)$ & $24.06(24.17)$ & $27.34(27.29)$ & $80.90(80.60)^{\mathrm{a}}$ \\
\hline \multirow[t]{2}{*}[\mathrm{Cu}_{2}\mathrm{L}_{5}(\mathrm{NO}_{3})_{2}]{$\left(\mathrm{NO}_{3}\right)_{2}$} & $180.0-265.0$ & $265.0-300.0$ & $300.0-530.0$ & $18.07(19.35)$ \\
\hline & $28.84(29.13)$ & $25.15(25.30)$ & $27.94(28.22)$ & $81.93(80.65)^{\mathrm{a}}$ \\
\hline
\end{tabular}

$\mathrm{a}=$ Total weight loss.

Table 4. Electrochemical data of copper(II) complexes

\begin{tabular}{|c|c|c|c|c|c|c|c|c|c|}
\hline Complexes & $E_{\mathrm{pc}}^{1}$ & $E_{\mathrm{pa}}^{1}$ & $E_{1 / 2}^{1}$ & $\Delta E$ & $E_{\mathrm{pc}}^{2}$ & $E_{\mathrm{pa}}^{2}$ & $E_{1 / 2}^{2}$ & $\Delta E$ & $K_{\mathrm{con}}$ \\
\hline$\left[\mathrm{Cu}_{2} \mathrm{~L}_{1}\left(\mathrm{NO}_{3}\right)_{2}\right]\left(\mathrm{NO}_{3}\right)_{2}$ & -0.83 & -0.69 & -0.74 & 140 & -1.09 & -0.95 & -1.02 & 110 & $3.6 \times 10^{4}$ \\
\hline$\left[\mathrm{Cu}_{2} \mathrm{~L}_{2}\left(\mathrm{NO}_{3}\right)_{2}\right]\left(\mathrm{NO}_{3}\right)_{2}$ & -1.03 & -0.91 & -0.95 & 110 & -1.35 & -1.25 & -1.29 & 100 & $3.7 \times 10^{5}$ \\
\hline$\left[\mathrm{Cu}_{2} \mathrm{~L}_{3}\left(\mathrm{NO}_{3}\right)_{2}\right]\left(\mathrm{NO}_{3}\right)_{2}$ & -0.54 & -0.44 & -0.46 & 100 & -0.88 & -0.80 & -0.85 & 90 & $2.6 \times 10^{6}$ \\
\hline$\left[\mathrm{Cu}_{2} \mathrm{~L}_{4}\left(\mathrm{NO}_{3}\right)_{2}\right]\left(\mathrm{NO}_{3}\right)_{2}$ & -0.49 & -0.38 & -0.45 & 90 & -0.66 & -0.63 & -0.65 & 60 & $3.4 \times 10^{3}$ \\
\hline$\left[\mathrm{Cu}_{2} \mathrm{~L}_{5}\left(\mathrm{NO}_{3}\right)_{2}\right]\left(\mathrm{NO}_{3}\right)_{2}$ & -0.56 & -0.32 & -0.42 & 250 & -0.89 & -0.77 & -0.83 & 110 & $5.6 \times 10^{6}$ \\
\hline
\end{tabular}

Measured by $\mathrm{CV}$ at $50 \mathrm{mV} / \mathrm{s}$. E versus $\mathrm{Ag} / \mathrm{AgCl}$. Conditions. Complex Conc. $=1 \times 10^{-3} \mathrm{M}$.

ion to the other metal ion and hence the second reduction appears at a high negative potential. The reduction waves are somewhat broad. This may be due to the equilibrium binding of the solvent to the $\mathrm{Cu}^{\mathrm{II}}$ centre. The peak broadening diminishes as the scan rate increases [22]. The first reduction wave appears in the potential range -0.48 to $-1.02 \mathrm{~V}$. The second reduction wave occurs in the potential range -0.68 to $-1.34 \mathrm{~V}$. The potentials at the first reduction waves of the $\left[\mathrm{Cu}_{2} \mathrm{~L}^{3-5}\right]$ are lower than for $\left[\mathrm{Cu}_{2} \mathrm{~L}^{1,2}\right]$. This indicates that $\left[\mathrm{Cu}_{2} \mathrm{~L}^{4,5}\right]$, with a ring environment (benzene and pyridine) are reduced more easily. The conproportionation constant for the equilibrium was calculated using the relationship $\log K_{\text {con }}=\Delta E / 0.0591$. A greater $K_{\text {con }}$ value indicates greater stability for the mixed valence species or that the exchange interaction is greater with respect to the isovalent species [23]. The conproportionation constant was calculated from the following equilibrium:

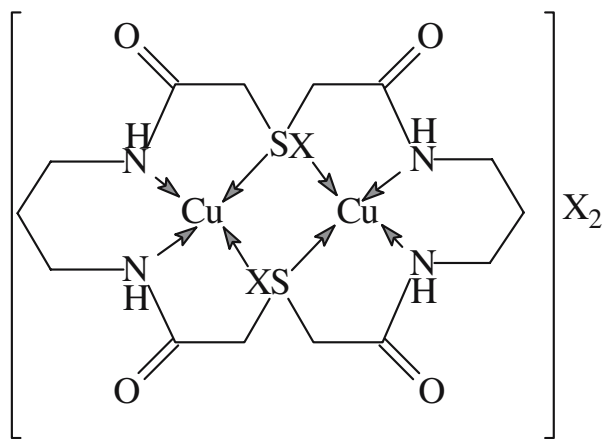

Fig. 2. Complexes with ligand $\mathrm{L}_{2}(1,7,11,17$-tetraaza-2,6,12,16-tetraone-4,14-dithia-cyclocosane) $\mathrm{X}=\mathrm{N}_{3}^{-}$.

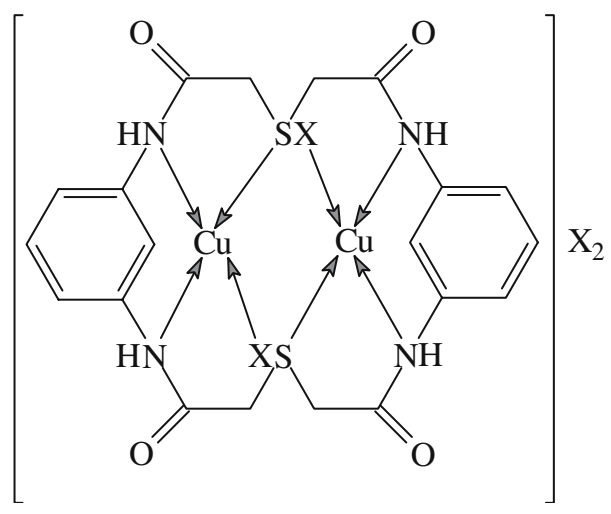

Fig. 3. Complexes with ligand $\mathrm{L}_{4}(1,7,14,20$-tetraaza-2,6,15,19-tetraone-4,17, dithiatricyclo $\left[22,4, \mathrm{O}^{21,26}, \mathrm{O}^{8,13}\right]$ hexacosa $8,10,12,21,23,25$ hexene) $\mathrm{X}=\mathrm{N}_{3}^{-}$.

$$
\begin{aligned}
& \mathrm{Cu}^{\mathrm{II}} \mathrm{Cu}^{\mathrm{II}} \leftrightarrows \mathrm{Cu}^{\mathrm{II}} \mathrm{Cu}^{\mathrm{I}} \leftrightarrows \mathrm{Cu}^{\mathrm{I}} \mathrm{Cu}^{\mathrm{I}}, \\
& \mathrm{CuCu}^{\mathrm{II}}+\mathrm{Cu}^{\mathrm{I}} \mathrm{Cu}^{\mathrm{I}} \leftrightarrows 2 \mathrm{Cu}^{\mathrm{II}} \mathrm{Cu}^{\mathrm{I}}
\end{aligned}
$$

Single crystals of the complexes could not be isolated from any solutions, thus no definitive structure may be described. However, the analytical, spectroscopic, magnetic data and thermal investigation enable us to predict the possible structures as shown in Figures 2 and 3.

\section{Acknowledgements}

The authors thank the director, NPL for providing the research facilities, and Ms Archna Gupta for recording EPR spectra. One of the authors, Rachna Gupta, thanks the CSIR for financial assistance. 


\section{References}

1. M.T.H. Tarafder, N. Saravanan and K.A. Crouse, Transition. Met. Chem., 26, 613 (2001).

2. M.A. Ali and M.T.H. Tarafder, J. Inorg. Nucl. Chem., 39, 173 (1977).

3. S. Chandra, K. Gupta and S. Sharma, Synth. React. Inorg. Met. Org. Chem., 31, 1205 (2001).

4. S. Chandra and K. Gupta, Transition Met. Chem., 27, 329 (2002).

5. M. Maji, M. Chatterjee, S. Ghosh, S.K. Chattopadhyay, B.M. Wu and T.C.W. Mak, J. Chem. Soc., Dalton Trans. 135 (1999).

6. P. Sengupta, R. Dinda, S. Ghosh and W.S. Sheldrick, Polyhedron, 22, 447 (2003).

7. S. Chandra and L.K. Gupta, Spectrochimica Acta, 60, 1563 (2004).

8. A. Chaudhary, N. Bansal, A. Gajraj and R.V. Singh, J. Inorganic Biochem., 96, 393 (2003).

9. G.A. Melson, Coordination Chemistry of Macrocylic Compounds, Plenum Press, New York, 1979.

10. R.H. Dixon., Reproductive Toxicology, Raven Press, New York, 1985, p. 309.

11. P. Schulfer, H. Oyanguren, V. Maturana, A. Valenzuela, E. Cruz, V. Plaza, E. Schmidt and R. Haddad, Ind. Med. Surg., 26, 167 (1957).
12. B.C. Gilbert, J.R. Lindsay Smith, A. Mairatai Payeras, J. Oakes and R. Ponsi Prats, J. Mol. catal. A, 219, 265 (2004).

13. V. Ayala, A. Corma, M. Iglesias and F. Sánchez, J. Mol. Catal. A, 221, 201 (2004).

14. S. Griveau, M. Gulppi, F. Bedioui and J.H. Zagal, Solid State Ionics, 169, 59 (2004).

15. S. Chandra, L. kumar Gupta and D. Jain, Spectrochimica Acta, 60, 2411 (2004).

16. B.J. Hathaway, in: J.N. Bradley and R.D. Gillard (Eds) Essays in Chemistry, Academic press, New York, 61, (1971).

17. K.K. Narang and A. Aggarwal, Ind. J. Chem., 13, 1072 (1975).

18. K. Nakamoto, Infrared Spectra of Inorganic and Coordination Compounds, Wiley Interscience, New York, 1970.

19. K. Gupta, Ph.D. Thesis, University of Delhi, Delhi, (2001).

20. A.B.P. Lever, Inorg Chem., 4, 763 (1955).

21. S.S. Tandon, L.K. Thompson and J.N. Bridson, Inorg. Chem., 32, 32 (1993).

22. M. Thirumavalavan, P. Akilan, M. Kandaswamy, K. Chinnakali, G. Senthilkumar and H.K. Fun, Inorg. Chem., 42, 3308 (2003).

23. R. Das and K. Nag, Inorg. Chem., 11, 941 (1992).

TMCH 6194 